\title{
Economic Contribution of Non-timber Forest Products (NTFPs) to Rural Livelihoods in the Tharawady District of Myanmar
}

\author{
Kyaw Thu Moe ${ }^{1}$, Junchang Liư 1
}

${ }^{1}$ School of Economics and Management, Beijing Forestry University, No (35), Qinghua East Road, Haidian District, Beijing, P.R. China, Post code -100083

\begin{abstract}
Non-timber forest products (NTFPs) income plays an important role in the household economy in the rural forest dwelling communities. This study use the data from 60 sample households of the three villages in Tharwady District of Myanmar to analysis the significant of NTFPs income in the rural household economy. Data collection was carried out through face to face household interview, focus group discussion, and government official interview. This study found that NTFPs income contributes $44.37 \%$, and farm income and non-farm income contribute $32.55 \%$ and $23.07 \%$ to the total household income respectively. The lower and middle income level households derived more NTFPs income than high income level households. For low income households, share of NTFPs income in the total household income is over 75\%. Major NTFPs include bamboo, thatch, firewood, charcoal, bamboo shoot, broom grass, bark and root, and others. Regression analysis showed that farm income, nonfarm income and agricultural land own are scientifically and negatively correlated with the NTFPs incomes. This study suggests that Community Forestry (CF) programmes together with extension and environmental education programmes should be encouraged in order to reduce dependence on the natural forests. In considering the CF programmes it should be encouraged the participation of low and middle income household.
\end{abstract}

Keywords: NTFPs, livelihoods, Tharawady District, Myanmar, NTFPs dependency, income level, CF

\section{Introduction}

Myanmar, the Republic of the Union of Myanmar, is endowed with rich natural resources arising from its different ecological diversity. Total land area of the country is more than 67.66 million hectares. About $46.67 \%$ of the country area is still covered with natural forests (Forest Department, 2014). As nearly half of the country area is covered with forests, these forests are home of different timer and non-timber forest products species. But Myanmar is the third greatest annual forest area reduction in the world (FAO, 2015). Drivers of deforestation and forest degradation include logging for domestic consumption and export, expansion of agriculture and tree plantations (especially rubber and oil palm plantations), shifting cultivation, infrastructure development, and poverty (Maung Maung Than, 2015). Myanmar forests are socially and economically significant to the country (Forest Department, 2014). According to census in 2014, population of the country is about 52 million. About $70 \%$ of the country population are rural community and depend on forest resources especially NTFPs for their subsistence and income needs.

The contribution of forests resources to rural livelihoods has global significance. Estimated amount of 1.6 billion rural people are dependent on forests to some extent, 1 billion out of 1.2 billion extreme poor depend on forest resources for all or part of their livelihoods and $300-350$ million people are highly dependent on forests and live within or adjacent to dense forests on which they depend for their subsistence and income (Cao, 2012). Collection and sale of NTFPs are a significant livelihood activity for the rural poor family (Vasundhara 1998) and play a significant role in household incomes (Melaku et. al. 2014, Bwalya 2013, Tarigan et.al 2010, Ros-Tonen 2000, Kamanga 2005, Ambrose-Oji 2003). Moreover they are important as an economic buffer and safety net for poor households when there is an economic hardship (Bryon \& Arnold 1997, Angelsen \& Wunder 2003, Vedeld et. al. 2004, Mulenga et. al. 2012, Shaanker et. al. 2003). A safety net is generally regarded as a source of emergency

This article is published under the terms of the Creative Commons Attribution License 4.0 Author(s) retain the copyright of this article. Publication rights with Alkhaer Publications.

Published at: http://www.ijsciences.com/pub/issue/2016-01/

DOI: 10.18483/ijSci.904; Online ISSN: 2305-3925; Print ISSN: 2410-4477 
sustenance in times of hardships (Shackleton et. al. 2011). NTFPs collection is attractive to poor people because sometimes it is open access and requires low skill and capital (Angelsen \& Wunder 2003).

The dependence on forest resources and contribution of forest resource to household vary across region. Angelson et. al. (2014) in their global comparative analysis on environmental income and rural livelihood found that environmental income accounts for $28 \%$ of total household income of which $77 \%$ comes from natural forests.Melaku et. al. (2014) reported in their study in Southwestern Ethiopia that the contribution of NTFPs to annual household income is $47 \%$. $50 \%$ of the income was from agriculture and remaining 3\% was from off-farm in. Dependency of local community on NTFPs was measured in Central Himalayan foot hills by Rijal et. al. (2010). This study estimated that NTFPs provided poorer households with a cash income share of 44$78 \%$. Jagger (2012) in western Uganda estimated that households in rural Uganda derive $26 \%$ of total household income from forests and other wild areas including fallows, agricultural lands, wetlands, grasslands, and shrub land. Saha and Sundriyal (2011) revealed that high dependence on wide variety of NTFPs in humid tropics of northeast India and NTFPs contributed to $19-32 \%$ of total household income for different tribal communities in northeast India. A case study from northern Benin, West Africa, by Heubach (2011) found that income from NTFPs accounted to $39 \%$ of total household income which is second largest after crop production of $44 \%$. Distribution of forest income among rural households was measured by Pyi Soe Aung et. al. (2014) in Natma Taung national park, Chin State of Myanmar revealed that the forest income is the first most important source of household income, contributing to about $50 \%$ to $55 \%$ of the total household income in two study villages.

A livelihood is defined as 'the activities, the assets, and the access that jointly determine the living gained by an individual or household' (Eills, 2000). Livelihoods are shaped by a multitude of different forces and factors that are themselves constantly shifting (DFID 1999). A sustainable livelihood comprises people, their capabilities and their means of living including food income and assets. A livelihood is environmental sustainable when it maintains or enhances the local and global assets on which livelihoods depend, and has net beneficial effects on other livelihoods. A livelihood is socially sustainable which can cope with and recover from stress and shocks, and provide for future generations (Chamber \& Conway 1991). Although income and livelihoods have different meanings, the level of household income is often used to measure the outcome of the livelihood process (Kamanga 2005). In considering the income, it consists of both subsistence and cash income.

Tharawady District, one of four districts of Bago region, is one of the most important districts for timber production because of its abundant forest resources. According to the district forest management plan, NTFPs, especially bamboo, play an important role in livelihood of rural community. NTFPs extraction is one of the major livelihood strategies for the rural poor especially landless poor family. Though NTFPs play an important role in the life of forest dwellers for cash income as well as subsistence needs, the value of NTFPs are undervalued. Even though the forest law of the country (Forest Law 1992) prohibited entering the reserved forests, there are a lot of encroachments within the forests. These households are landless poor and they have no land for agriculture. On the other hand forest resources provide shelters for them almost free of charges in monetary terms. Forest Department cannot control these illegal encroachments and currently tries to change these illegal encroachments to become legal. Some part of reserved forest lands are declared as communal own land on which these illegal encroachments are settled. In order to formulate policy regarding to these illegal encroachment, the role of NTFPs income in the household economy is necessary to understand. In the literature, there is no previous study regarding to the contribution of NTFPs to the local community in the study area. This study tried to explore the major sources of livelihoods in the study area and the role of NTFPs income in their livelihoods. This study tried to fulfill the gap of knowledge in the importance of NTFPs income to rural household by the quantitative analysis. The major objective of the paper is to investigate the economic contribution of NTFPs to the rural household income in Tharawady District of Myanmar. This paper tries to answer (i) what is the share of NTFPs income in the total household income, (ii) what factors determine the engagement of rural household in NTFPs collection, and (iii) how socioeconomic characteristics determine household dependence on income from NTFPs?

\section{Study area and data collection}

\subsection{Study area}

The study was conducted in the Tharawady District, West Bago Region of Myanmar. Bago Region is situated in the southern central part of Myanmar between the latitudes of $19^{\circ} 20^{\prime} \mathrm{N}$ and $46^{\circ} 45^{\prime} \mathrm{N}$ and longitudes of $94^{\circ} 35^{\prime} \mathrm{E}$ and $97^{\circ} 10^{\prime} \mathrm{E}$. The Region occupies an area of about 15212 sq miles and consists of four districts, Bago, Taungoo, Pyay and Tharawady. Bago Yoma, (Yoma is Myanmar name 
literally means hill) is the mountain range running about 300 miles from north to south. It divides the western part (Pyay and Tharawady) and eastern part (Bago and Taungoo) of the Bago Region. Bago Yoma sometimes refers to as "Home of Teak" because teak which grows on the Yoma is of highest quality. Abundant growth of different bamboo species can be occurred. The soil is deep and fertile, richness in timber and bamboo species, better transport nowadays attract landless poor people to settle in the forest and expand agricultural land. According to the integrated household living conditions survey in Myanmar which has been published in 2011, Bago region is the highest rate of landless with $41 \%$ (UNDP, 2011).

Tharawaddy District is situated between the Latitude of $17^{\circ} 28^{\prime} \mathrm{N}$ and $18^{\circ} 48^{\prime} \mathrm{N}$ and Longitudes of $95^{\circ} 10^{\prime} \mathrm{E}$ and $96^{\circ} 5^{\prime} \mathrm{E}$. It consists of 8 Townships, Tharawaddy, Letpandan, Moenyo, Minhla, Oakpho, Kyopinkauk, Zeegon and Nattalin. Total area is 2803.36 sq mile $(1794151$ Ac) and population in $2009-2010$ is 1004944. Average temperature is about $27.02^{\circ} \mathrm{C}$ and average rainfall is about 84.33 inches. The major forest type of the district is Upper Mixed Deciduous Forest where economically important species such as Teak (Tectona grandis L.f) and Pyinkado (Xylia xylocarpa (Roxb.) Taub.) can be found profusely. Evergreen Forest can also be found in some area where tree species such as Kanyin (Dipterocarpus alatus Roxb.), Leza (Lagerstroemin tomentosa Presl), Thingyan (Hopea odorata Roxb), etc. can be found. Major bamboo species are KyathaungWa (Bambusa polymorpha Munro), ThiekWa (Bambusa tulda Roxb.), YinWa (Cephalostachyum pergracile Munro). Bamboo plays an important role in the livelihood of rural community (Tharawaddy District Forest Departement, 2010).

\subsection{Data collection}

In selecting the villages to be sampled, purposive sampling was used to select the villages. The three villages in two townships (Bo Gyi Kone Village and We Ywa Thit Village of Tharawady Township and Ban Bway Kone Village of Min Hla Township) of Tharawady District were chosen for data collection. Before the selection of Township and sample villages, reconnaissance survey was carried out. Together with the reconnaissance survey, testing of the prepared questionnaires were carried out. Study villages were selected based on (1) representativeness of the region, (2) distance from urban area, (3) distance from forest, (4) distance from NTFP marketing place, (5) village size (number of household in the village), (6) accessibility, (7) forest types. The primary data were collected through face to face household interview.

Table 1: Information of the three villages

\begin{tabular}{|l|c|c|c|}
\hline \multicolumn{1}{|c|}{ Village name } & Township name & Total household & Population \\
\hline Bo Gyi Kone & Tharawady & 37 & 157 \\
\hline We Ywa Thit & Tharawady & 67 & 261 \\
\hline Ban Bway Kone & Min Hla & 103 & 473 \\
\hline
\end{tabular}

Total households sampled were 60 households. The households were selected by Simple Random Sampling method. Most of the questionnaires were answered by household head. In the absence of household head, the members of households who can answer the questionnaires and have knowledge of the household characteristics were selected for interview. In addition to face to face interview, focus group discussion to supplement information regarding to NTFPs usage were done. Focus group discussions were carried out with the village leaders and villagers and each group contained $5-6$ people. In addition to the primary data, secondary data were collected from Government offices, including township level, district level and also head office of Forest Department.

\section{Methodology}

\subsection{Income accounting}

This study focus on the income derived from forest resources. Incomes are accounted by Myanmar currency (Kyat). According to the exchange rate by central bank of Myanmar 1 US\$ is equal to about 1300 Kyats. Following Cavendish (2002), this study used the total net income (subsistence and cash) approach. It focuses on three major sources of income as resulted from the household face to face interview and focus group discussion such as farm income, non-farm income and NTFPs income. Total household income was estimated as follow.

Total household income $=\Sigma$ (Agricultural income + Non-farm income + NTFPs income)

These three major incomes were estimated as follows.

\section{Farm income}

Farm income in this study includes incomes from agricultural crops and incomes from livestock. In calculating agricultural crop income, all incomes generated from farming are accounted. Both subsistence and cash income from farming are calculated as agricultural income. The quantity of crop yields was obtained from individual households through face to face household interviews. Reported 
price of each products by household itself are used in calculation. Reported prices for each seasonal product are same as they sold their products in the local markets almost at the same time. Agricultural income is calculated by multiplying the crop yields with respective prices of the products. Agricultural income used in this study is net income from agriculture because the value of inputs such as seeds, fertilizer, labor cost (only hired labor cost is considered and cost of owned labor is not included in the calculation Cavendish (2002)), etc. are deducted from the total income. The common livestock in the study area are pig, buffalo and cow but since the households in the study area are poor they cannot afford to rear livestock. In order to calculate the annual income stream from livestock grazing, this study use the method proposed by Cavendish (2002). According to Cavendish (2002), the price of a livestock unit should reflect the net present value of its entire future income stream. He assumed that cattle are a frictionless production technology, merely converting food inputs into useful outputs at $100 \%$ efficiency and with no value added in and of themselves. With this assumption, it becomes possible to use livestock prices to calculate an income stream over time that will equal the value of all fodder inputs. He proposed following income stream formula,

$$
Y_{0}=P_{0} \frac{r}{r-(1 /(1+r))^{T}}
$$

Where, $\mathrm{Y}_{0}=$ the current year livestock income stream $\mathrm{T}=$ lifespan of the livestock measure from the current date

$$
\mathrm{r}=\text { the discount rate }(10 \%)
$$

$\mathrm{P}_{0}=$ the current price of the livestock unit based on own reported price

\section{Non-farm income}

Non-farm include all income form the wage labor, permanent employment such as pension, government staff, private shops, income obtained from property. Wage labor in the study area is mostly in the agricultural activities. There is also other source for wage labor which is private plantations such as teak and other hardwood plantations established by the company or individuals. The daily wages for man and woman are not the same. The wage rate and number of working days/hours reported by the respondents is used in the estimation. Income from pension, private shops, etc. is obtained from the individual household through face to face interview.

\section{NTFPs income}

In the study area, the major NTFP is bamboo. Forest management plan of Tharawady District emphasizes the importance of bamboo for livelihood of local community. Bamboo is the major income sources for most households. Household reported market prices are used for estimation of income from NTFPs. In the study area, bamboo is widely traded locally. Other important products and income sources include bamboo shoot, charcoal, firewood, broom grass. Income from NTFPs was estimated as the gross monetary values (Cavendish 2002) of all products collected by a household both for subsistence and for commercial use. This paper used the definition of FAO for NTFPs, "goods of biological origin other than wood derived from forests, other wooded lands and trees outside forests". Income from commercial products was estimated by multiplying household reported quantity and price. In the case of products that household cannot valuate, substituted price, assumption and omission were used to estimate the value of the products.

\subsection{Data analysis}

Both descriptive statistics (mean, sd, etc.) and econometric analysis were used. The collected data were analysis using Excel 2010 and STATA version 13. Descriptive statistics were used to analysis mean, standard deviation, etc. Econometrics analysis were used to analysis the relationships between NTFPs income and household characteristics and to analyze the factors influencing the household involvement in NTFPs collection.

\subsection{Comparison of NTFPs income among different income level}

In order to compare different income groups regarding to different NTFPs income level, the samples were split into three different income levels based on total household income. Each level contains same number of household. Non-parametric KruskalWallis test was used to analyze the differences of income across different income level.

\subsection{NTFPs dependency model}

NTFPs dependency was measured as the share of NTFPs income in total household income (relative NTFPs income) as described in Vedeld et. al. (2004). NTFPs dependency was estimated in order to point out the contribution of NTFPs income to total household income and to measure the degree of dependence on NTFPs. In considering the share of NTFPs income in total household income both subsistence and cash value were taken into account. Ordinary least regression was run in order to identify which socioeconomic variables influence on NTFPs income. The NTFPs income was considered as the dependent variable and household characteristics such as age of the household head, sex of the household head, education of the household head, household size, agricultural land holding, off-farm income, agricultural income and total household 
income were considered as independent explanatory variables. The econometric model can be stated as follow.

$\boldsymbol{Y}=\boldsymbol{\beta}_{0}+\boldsymbol{\beta}_{1} \boldsymbol{x}_{\boldsymbol{i}}+\boldsymbol{u}$

Where, $Y=$ NTFPs income,

$\beta_{0}=$ intercept, $\beta_{1}=$ estimated coefficient of explanatory variable $\mathrm{x}_{\mathrm{i}}$,

$\mathrm{x}_{\mathrm{i}}=$ explanatory variables (household

characteristics),

$\mathrm{u}=$ error term

\section{Result and discussion}

Results presented below were based on the questionnaire survey made in the period of August and September 2015. The recall period for household income was one year. The questionnaire survey was carried out with the assistance of two forestry graduates who had previous experiences in the household questionnaires survey.

\subsection{Demographic and socioeconomics characteristics of the households}

The average family size in the study villages was 4.5 with a minimum of 1 and maximum of 9 household members. Among the respondents, $8.33 \%$ of the household was female headed household and $91.67 \%$ of was male headed household. The average education level is 3.7 years, among them most of the household headed were not accessed to formal education. They have accessed to education in the monastery. Average age of the household heads was 46.23 years with a minimum of 22 years and maximum of 77 years old. Only $25 \%$ of the household own agricultural land and the remaining households are agricultural landless. The average agricultural land size is 1.09 acre. $61.67 \%$ of the household were engaged in non-farm activities, these include wage labor in agriculture, wage labor in private forest plantations, private shops, etc. Most households $(75 \%)$ were not native to the villages. Their motivation for moving to the villages was the villages are near to the forests and they have easily access to the forest resources even though access to forest resources in the reserved forests is strictly prohibited by the law. The descriptive statistics of household characteristics are shown in table 2 .

Table 2: Descriptive statistics of Household characteristics

\begin{tabular}{|l|c|c|c|c|}
\hline $\begin{array}{l}\text { Household } \\
\text { Characteristics }\end{array}$ & $\begin{array}{c}\text { Family } \\
\text { size }\end{array}$ & $\begin{array}{c}\text { Age } \\
\text { (Year) }\end{array}$ & $\begin{array}{c}\text { Education } \\
\text { (Year) }\end{array}$ & $\begin{array}{c}\text { Agri-land } \\
\text { (Ac) }\end{array}$ \\
\hline Minimum & 1 & 22 & 0 & 0 \\
\hline Maximum & 9 & 77 & 11 & 12 \\
\hline Mean & 4.53 & 46.23 & 3.7 & 1.09 \\
\hline Standard deviation & 1.56 & 13.33 & 2.23 & 2.31 \\
\hline Standard error & 0.20 & 1.72 & 0.29 & 0.30 \\
\hline
\end{tabular}

\subsection{Economic contribution of NTFPs}

The major livelihood strategies in the study area are farming (agriculture + livestock), non-farm activities and NTFPs collection. As shown in the table 3, income from NTFPs was the major and highest income sources $(44.37 \%$ share to the total household income) in the study villages. This includes both subsistence and cash income. Agricultural income is the second largest share with $32.55 \%$ and non-farm income share of $23.07 \%$. The income from NTFPs is relatively high in comparing to other studies. Saha and Sundriyal (2011) revealed that high dependence on wide variety of NTFPs in humid tropics of northeast India and NTFPs contributed to $19-32 \%$ of total household income for different tribal communities in northeast India. Melaku et. al. (2014) reported in their study in Southwestern Ethiopia that the contribution of NTFPs to annual household income is $47 \%$. The percentage share is higher than this study but the difference is that in this study NTFPs are the major income sources. In their study, $50 \%$ of the income was from agriculture and remaining $3 \%$ was from off-farm in. A study made by Mamo, Sjaastad and Vedeld (2006) in Dendi District of Ethiopia estimated that income from forest resources contributed to $39 \%$ of the average household income which is roughly equal to agricultural income $40 \%$.

But this result supports the finding of Pyi Soe Aung et. al. (2014) in Natma Taung national park, Chin State of Myanmar revealed that the forest income is the first most important source of household income, contributing to about $50 \%$ to $55 \%$ of the total household income in two study villages. 
Table 3: Average annual household income

\begin{tabular}{|l|c|c|c|c|}
\hline \multicolumn{1}{|c|}{ Type of Income } & $\begin{array}{c}\text { Average Income per year } \\
\text { (Kyats/Year/household) }\end{array}$ & $\begin{array}{c}\text { Standard } \\
\text { deviation }\end{array}$ & $\begin{array}{c}\text { Standard } \\
\text { error }\end{array}$ & $\begin{array}{c}\text { Income share } \\
(\%)\end{array}$ \\
\hline Farm Income & 409575 & 648220 & 83685 & 32.55 \\
\hline Non-farm Income & 290273 & 558258 & 72223 & 23.07 \\
\hline NTFPs Income & 558325 & 303553 & 39189 & 44.37 \\
\hline Total Income & 1258107 & 744889 & 96165 & \\
\hline
\end{tabular}

The major NTFPs that contributed to household income are shown in the table 4. As described in the management plan of Tharawady District, this study empirically pointed out that bamboo is the most important NTFPs which contribute to socioeconomic development of the local community. Nearly $77 \%$ of sampled household engaged in bamboo collection and income share in NTFPs income from bamboo is over $70 \%$. This include both subsistence and cash income but predominately cash income. For the cash purpose they sold bamboo raw through local brokers. In the rainy season, the means of the transportation is waterway. They made a bamboo raft and then transport through water flow. In the winter and summer, the traders come to buy to the production sites because it is accessible to the forest in the winter and summer. Second largest share in NTFPs income is from firewood. Almost $97 \%$ of sample households engaged in firewood collection and the remaining households are not engaged in firewood collection but they buy firewood from others collectors. Income share from Thatch, charcoal, bamboo shoot, broom grass, bark/root, and others are $6.55 \%, 0.52 \%, 0.87 \%$, $2.45 \%, 1.04 \%$ and $3.85 \%$ respectively.

All respondent think that the NTFPs resources are dwindling because the distance to the forest area is longer than previous three to five years. According to the respondent, the major causes of dwindling include increasing population which also increases NTFPs collectors, establishment of private forest plantation.

Table 4: Major NTFPs and income share to NTFPs income

\begin{tabular}{|l|r|r|r|}
\hline \multicolumn{1}{|c|}{ NTFPs } & $\begin{array}{c}\text { No. of engaged } \\
\text { households }\end{array}$ & $\begin{array}{c}\text { Proportion (\%) of } \\
\text { household engaged }\end{array}$ & $\begin{array}{c}\text { Proportion (\%) in } \\
\text { NTFPs income }\end{array}$ \\
\hline Bamboo & 46 & 76.67 & 70.09 \\
\hline Thatch & 22 & 36.67 & 6.55 \\
\hline Firewood & 58 & 96.67 & 14.64 \\
\hline Charcoal & 2 & 3.33 & 0.52 \\
\hline Bamboo shoot & 2 & 3.33 & 0.87 \\
\hline Broom Grass & 9 & 15 & 2.45 \\
\hline Bark+root & 4 & 6.67 & 1.04 \\
\hline Others & 9 & 14.49 & 3.85 \\
\hline
\end{tabular}

\subsection{NTFPs income among different income} levels

In term of absolute value, the income from NTFPs is relatively higher in the low and middle level (Table 5). The income share from NTFPs in the high income level is only $23.31 \%$ and in the middle income level is about $67.44 \%$. Lower income level received highest income from NTFPs which contribute to over $75 \%$ too the total income. This is because high income level household own agricultural land and better off-farm jobs such as private shop, large livestock, etc. The low income and middle income households are normally landless and they are totally depended on forest resources for their daily necessity. This result is contradictory to the findings of Pyi Soe
Aung et. al. (2014). They found that the better off household (high income level in this study) received highest income from forest resources. Mamo et. al. (2006) also found that the rich households derive a larger absolute income from forest resources than the poor households. But this study supports the findings of Rijal et. al. (2010). They found that better off household are not NTFPs dependent but rely on income from crop production and livestock. This study also confirmed the finding of the study of Kar \& Jacobson (2011) in Bangladesh. Their study found that the poor households are relatively more dependent on NTFPs for their subsistence and cash income than the better off households. 
Table 5: Income sources by income level (Average)

\begin{tabular}{|l|c|c|c|c|c|c|l|}
\hline \multirow{2}{*}{ Income source } & \multicolumn{2}{|c|}{$\begin{array}{c}\text { High income } \\
(\mathbf{n = 2 0})\end{array}$} & \multicolumn{2}{|c|}{$\begin{array}{c}\text { Medium income } \\
(\mathbf{n = 2 0})\end{array}$} & \multicolumn{2}{c|}{$\begin{array}{c}\text { Low income } \\
(\mathbf{n = 2 0})\end{array}$} & \multirow{2}{*}{ Kruskal-Wallis test } \\
\cline { 2 - 7 } & Income & $\%$ & Income & \% & Income & \% & \\
\hline Farm income & 988690 & 47.27 & 214783 & 21.25 & 25254 & 3.76 & $\mathrm{p}=0.0001, X^{2}=23.594, \mathrm{df}=2$ \\
\hline Non-farm income & 615500 & 29.42 & 114270 & 11.31 & 141050 & 20.99 & $\mathrm{p}=0.143, X^{2}=3.887, \mathrm{df}=2$ \\
\hline NTFP income & 487600 & 23.31 & 681500 & 67.44 & 505675 & 75.25 & $\mathrm{p}=0.075, X^{2}=5.182, \mathrm{df}=2$ \\
\hline
\end{tabular}

\subsection{NTFPs dependency models}

Two OLS regressions were run, NTFPs income against household socioeconomic variables and NTFPs income against other income sources. Among the explanatory variables in the first model, agricultural land $(\mathrm{p}<0.01)$ is the statistically significant and negatively correlated with the NTFPs income (Table: 6). Agricultural land is the most important factor that is likely to reduce the dependency of local community on NTFPs. This result supports the findings of other studies (e.g. Mamo et. al. 2007, Heubach et. al. 2011). Babulo et al. (2008) also found that households with large plots of land were less likely to engage in forest extraction as their dominant strategy. Age is negatively correlated with the NTFPs income. This result is in line with Cavendish (2000), Angelson et. al. (2014), Melaku et. al (2014), Masozera (2002). Number of working people $(\mathrm{p}<0.1)$ and education of household head $(\mathrm{p}<0.05)$ are statistically significant and positively correlated with the NTFPs income. Larger household may tend to have more number of working people. Household with larger number of working people may tend to involve more in the NTFPs collections. Other studies such as Melaku et. al. (2014), Pyi Soe Aung et. al. (2014), Masozera (2002) used household size as an explanatory variable. They found that household size was positively correlated. Education of the household head was expected to be negatively correlated with NTFPs income but it was positively correlated. This result is contradictory to the general findings of other studies but Masozera (2002) also found the positive coefficient of education. Looking at the average age of the household head in the study area, it can be found between 22 and 77. In Myanmar, most of the older rural people were not accessed to formal education. They have accessed to education in village monastery. But nowadays, younger people get access to formal education but mostly primary education. Therefore the education was positively correlated with the NTFPs income. Illukpitiya \& Yanagida (2008) found that the effect of education on forest dependency may have been complicated by the unemployment among educated households hence causing unexpected results in variables related to education. Sex of household head was positively correlated to the NTFPs income.

Table 6: OLS regression of NTFPs income against household socioeconomic variables

\begin{tabular}{lccc}
\hline \multicolumn{1}{c}{ Variables } & Estimated coefficient & $\mathbf{t}$ ratio & $\mathbf{P}>|\mathbf{t}|$ \\
\hline Sex of HHH & 216,410 & 1.64 & 0.106 \\
& $(131,623)$ & & 0.395 \\
Age of HHH & $-2,615$ & -0.86 & \\
\hline Working people & $(3,050)$ & & 0.078 \\
\hline Education of HHH & $62,195^{*}$ & 1.80 & 0.026 \\
& $(34,606)$ & 2.29 & 0.006 \\
\hline Agri-Land Own Ac & $37,523^{* *}$ & & \\
\hline Constant & $(16,399)$ & -2.86 & 0.214 \\
& $\left(16,514^{* * *}\right.$ & & \\
\hline
\end{tabular}

Observation $=60, \mathrm{R}$-squared $=0.293, \mathrm{R}$-squared $($ adjusted $)=0.227, \mathrm{~F}=4.47$,

Prob $>\mathrm{F}=0.0018$, Standard errors in parentheses, $* * * \mathrm{p}<0.01, * * \mathrm{p}<0.05, * \mathrm{p}<0.1$

Farm income in this paper encompass both agricultural and livestock incomes. Farm income $(\mathrm{p}<0.01)$ was negatively correlated to NTFPs income and statistically significant. This means that households with more income from agriculture and livestock less dependent on NTFPs resources. This result is in line with the finding of Illukpitiya \& Yanagida (2008). They stated that forest dependency decreased for households with more diversified income sources and sources of diversify household income include agriculture, livelihood production, etc. But this result is opposite to the findings of 
Angelsen et. al. (2014). They found in their global comparative analysis on environmental income study that agricultural land ownership is positively correlated with higher environmental reliance.
Moreover Melaku et. al. (2014) found that total land holding showed positive relation to income derived from

NTFPs.

Table 7: OLS regression of NTFPs income against other income sources

\begin{tabular}{lccc}
\hline Variables & Estimated coefficient & t ratio & $\mathbf{P}>|\mathbf{t}|$ \\
\hline Farm Income & $-0.176^{* * *}$ & -3.30 & 0.002 \\
& $(0.0534)$ & & \\
\hline Non-farm Income & $-0.187^{* * *}$ & -3.03 & 0.004 \\
& $(0.0619)$ & & \\
\hline Constant & $684,799^{* * *}$ & & \\
& $(44,614)$ & &
\end{tabular}

Observation $=60, \mathrm{R}$-squared $=0.258$, R-squared $($ adjusted $)=0.232, \mathrm{~F}=9.90$,

Prob $>\mathrm{F}=0.0002$ Standard errors in parentheses, $* * * \mathrm{p}<0.01, * * \mathrm{p}<0.05, * \mathrm{p}<0.1$

Kamanga et. al. (2008) also found that households with lower agricultural income engage less in communal forest income generation. NTFPs dependency was reduced if the household have better non-farm employment. Non-farm income was statistically significant and negatively correlated to NTFPs income. Rayamajhi (2012) also reported that the more income from outside and the more savings, the less households rely on forests. In terms of sustainable livelihood framework, the dependence on natural capital reduces when there is more physical capital such as agricultural land.

\section{Conclusion and recommendation}

Major income sources in the study area include farm income, non-farm income and NTFPs income. This study found that income from NTFPs plays an important role in the livelihood of local community. Households engaged in NTFPs collection for different subsistence and commercial purpose. Thus study found that NTFPs income is the highest share in the total household income amounted to $44.37 \%$, farm income is the second largest share after NTFPs income amounted to $32.55 \%$ and non-farm income amounted to $23.07 \%$. Among different NTFPs, bamboo is the most important NTFPs with the highest income share in NTFPs income with over $70 \%$. Moreover nearly $77 \%$ of the household engaged in bamboo collections. Second most important NTFPs is firewood. Firewood is mainly for consumption purpose but some households collect firewood for commercial purpose, only two to three household collect for commercial purpose. The major NTFPs reported by households include Thatch, charcoal, bamboo shoot, broom grass, bark/root and others. This study also found that lowest income level households derive more income from NTFPs than high income level households. Low income households are normally landless poor. They depend only on forest resources for their daily necessity. Forest resources particularly NTFPs constitute the main source of income for the households in the low and middle income groups. Farm income and nonfarm income are negatively correlated with NTFPs income. This means that local community less dependent on NTFPs if they have access to better non-farm activities and agricultural land. It also found that agricultural land is significantly and negatively correlated with the NTFPs income.

As the forest policy (1995) of Myanmar emphasize people participation as one of the six imperatives, the results of this study are important to inform politician and decision makers so as to consider participatory approach in the management of forest resources because income from forest resources constitute major income source for rural forest dwellers. Management decisions without considering the role of forest for rural forest dwellers especially low and middle income households could not reach expected goals. Policy enforcement could be improved with the involvement of rural people in forest conservation by addressing the needs of the dependent communities and their livelihood (Illukpitiya \& Yanagida 2008). This study could be used as the one of the scientific guidance pointing out the role of forest dependent communities in management of natural forest resources.

According to the study result, majority of local community depends on bamboo resources for cash income and almost all of the respondents revealed that the resources are declining. This means that there was excessive utilization of the resources. It is sure that complete protection of the forests is impossible. Various NGOs and INGOs and GOs should take into account to find the way how local community can diversify their livelihoods options instead of depending on the certain resources. Moreover the provision of training and skills, such as producing value-added products instead of marketing raw, could reduce excessive utilization of certain resources. Community forestry $(\mathrm{CF})$ programmes together with extension and environmental education programmes 
should be encouraged in order to reduce dependence on the natural forests. In considering the $\mathrm{CF}$ programmes it should be encouraged the participation of low and middle income households.

\section{Acknowledgements}

The authors are grateful to APFNet (Asia Pacific Network for Sustainable Forest Management and Rehabilitation) for granting the scholarship for the first author to pursue M. Sc. degree in Forest Economics and Management in Beijing Forestry University. We also thank to Forest Department of Tharawady District, Tharawady Township, Letpandan Township for their help throughout field data collection. We also thank to Forest Department, Ministry of Environmental and Forestry for allowing the first author to participate in the master degree program.

\section{References}

1. AMBROSE-OJI B. 2003. The contribution of NTFPs to the livelihoods of the 'forest poor': evidence from the tropical forest zone of south-west Cameroon. International Forestry Review 5(2). 2003.

2. ANGELSEN, A. ET AL. 2014. Environmental Income and Rural Livelihoods: A Global-Comparative Analysis. World Development Vol. 64, pp. S12-S28. 2014. http://dx.doi.org/10.1016/j.worlddev.2014.03.006

3. ANGELSEN, A., LARSEN, H. O., LUND, J. F., SMITHHALL, C., WUNDER, S. 2011. Measuring livelihoods and environmental dependence: methods for research and fieldwork, Centre for International Forestry Research (CIFOR), Bogor, Indonesia

4. ANGELSEN, A. WUNDER, S. 2003. Exploring the Forest Poverty Link: Key Concepts, Issues and Research Implications. International Forestry Research (CIFOR), Bogor, Indonesia

5. BABULO, B. ET AL. 2008. The economic contribution of forest resource use to rural livelihoods in Tigray. Forest policy and Economics 11(2009) 109-117.

6. BABULO, B. ET AL. 2008. Household livelihood strategies and forest dependence in the highlands of Tigray, Northern Ethiopia. Agricultural Systems 98 (2008) 147-155.

7. BELCHER, B.M. 2003. What isn't an NTFP? International Forestry Review 5(2). 2003.

8. BRYON, N. \& ARNOLD, M. 1997. What futures for the people of the tropical forests? Centre for International Forestry Research (CIFOR), Bogor, Indonesia

9. BWALYA. 2011. Household dependence on forest income in rural Zambia. Zambia Social Science Journal

10. CAO. 2012. Forest Peoples: Numbers across the world. Forest People Program.

11. CAVENDISH, W. 2000. Empirical Regularities in the Poverty-Environment Relationship of rural Households: Evidence from Zimbabwe. World Development Vol. 28, No. 11 , pp. $1979 \pm 2003.2000$

12. CAVENDISH, W. 2002. Quantitative methods for estimating the economic value of resource use to rural households. In: Campbell, M.B., Luckert, K.M. (Eds.), Uncovering the Hidden Harvest: Valuation Methods for Woodland and Forest Resources. Earthscan Publications Ltd., London.

13. CHAMBERS R. and CONWAY G. R. 1991. Sustainable rural livelihoods: practical concept for the $21^{\text {st }}$ century. IDS Discussion paper 296

14. DFID. 1999. Sustainable livelihoods guidance sheets. Department for International Development. London, UK.
15. ELLIS, F. 1999. Rural livelihood diversity in developing countries: evidence and policy implications. Natural resource perspectives. Number 40, April 1999

16. FOREST DEPARTMENT. 2014. Facts about environmental conservation and forestry in Myanmar. Ministry of Environmental Conservation and Forestry, June 2014.

17. FAO. 2008. Socio-economic and livelihoods analysis in investment planning; key principles and methods. Food and Agricultural Organization of United Nations. Rome

18. FAO. 2014. State of the world's forest. Enhancing the socioeconomic benefits from forests. Food and Agricultural Organization of United Nations. Rome

19. FAO. 2015. Global Forest Resource Assessment. Food and Agricultural Organization of United Nations. Rome

20. FOREST DEPARTMENT. 2014. Facts about Environmental conservation and forestry in Myanmar. Ministry of Environmental Conservation and Forestry

21. HEUBACH, K. ET AL. 2011. The economic importance of non-timber forest products (NTFPs) for livelihood maintenance of rural west African communities: A case study from northern Benin, Ecological Economics 70 (2011)19912001.

22. ILLUKPITIYA, P. and YANAGIDA J. F. 2008. Role of income diversification in protecting natural forests: evidence from rural households in forest margins of Siri Lanka. Agroforest Syst (2008) 74:51-62, DOI 10.1007/s10457-0089153-2

23. JAGGER, P. 2012. Environmental income, rural livelihoods, and income inequality in western Uganda. Forests, Trees and Livelihoods. DOI:10.1080/14728028.2012.698846

24. JAGGER, P., ET AL. 2012. Asking Questions to Understand Rural Livelihoods: Comparing Disaggregated vs. Aggregated Approaches to Household Livelihood Questionnaires. World Development Vol. 40, No. 9, pp. 1810-1823, 2012 http://dx.doi.org/10.1016/j.worlddev.2012.04.030

25. KAMANGA, P. 2005. Forest Environmental incomes and rural livelihoods in Chiradzulu District Malawi. M. Sc Thesis. Norwegian University of Life Sciences

26. KAMANGA, P., VEDELD, P., SJAASTAD, E. 2008. Forest incomes and rural livelihoods in Chiradzulu District, Malawi. Ecological Economics 68(2009) 613-624.

27. KAR S. P. and JACOBSON, M.G. 2011. NTFP income contribution to household economy and related socioeconomic factors: Lessons from Bangladesh. Forest Policy and Economics 14 (2012) 136-142.

28. KHIN MAUNG LWIN. 1995. Myanmar. In Beyond timber: social, economic and cultural dimensions of non-wood forest products in Asia and the Pacific. RAP Publication 1995/13. Bangkok, FAO Regional Office for Asia and the Pacific.

29. MAMO, G., SJAASTAD, E. AND VEDELD, P. 2006 Economic dependence on forest resources: A case from Dendi District, Ethiopia. Forest Policy and Economics 9 (2007) 916-927

30. MASOZERA, M. K., 2002, Socioeconomic impact analysis of the conservation of the Nyungwe Forest Reserve, Rawanda. M. Sc Thesis, University of Florida.

31. MAUNG MAUNG THAN. 2015. Drivers of forest change in the greater Mekong sub-region. Myanmar country report

32. MELAKU, E., EWNETU, Z., TEKETAY, D. 2014. Nontimber forest products and household incomes in Bonga forest area, Southwestern Ethiopia. Journal of Forestry Research (2014) 25(1):215-223, DOI 10.1007/s11676-0140447-0

33. MULENGA, B. P., RICHARDSON, R. B. and TEMBO, G., 2012, Non-timber forest products and rural poverty alleviation in Zambia, Indaba Agricultutal Policy Research Institute (IAPRI), Lusaka, Zambia

34. NEUMANN, R. P. and HIRSCH, E. 2000 Commercialisation of non-timber forest products: Review and analysis of research. Bogor, Indonesia: Center for International Forestry Research; Rome: FAO.

35. PYI SOE AUNG, YAHIA OMAR ADAM, JÜRGEN PRETZSCH AND RONNY PETERS. 2014. Distribution of 
forest income among rural households: a case study from Natma Taung national park, Myanmar. Forests, Trees and Livelihoods. DOI: 10.1080/14728028.2014.976597

36. RAYAMAJHI, S., SMITH-HALl, C., HELlES, F. 2012. Empirical evidence of the economic importance of Central Himalayan forests to rural households. Forest Policy and Economics 20 (2012) 25-35.

37. RIJAL, A., SMITH-HALL, C, HELlES, F. 2010. Nontimber forest product dependency in the Central Himalayan foot hills. Environ Dev Sustain (2011) 13:121-140, DOI 10.1007/s10668-010-9252-x

38. ROS-TONEN, M.A.F. 2000. The role of Non-timber Forest Products in tropical forest management. Holz als Roh-und Werkstoff 58 (2000) 196-201

39. S. JHA. 2008. Household-specific variables and forest dependency in an Indian hotspot of biodiversity: challenge for sustainable livelihoods. Environ Dev Sustain (2009) 11:1215-1223, DOI 10.1007/s10668-008-9175-y

40. SAHA, D. \& SUNDRIYAL, R.C. 2011. Utilization of nontimber forest products in humid tropics: Implications for management and livelihood. Forest Policy and Economics 14 (2012) 28-40

41. SHACKLETON, S., SHANLEY, P. and NDOYE, O. 2007. Invisible but visible: recognizing local markets for nontimber forest products. International Forestry Review Vol. 9 (3)

42. ShaCKLETON, S., Shackleton, C., Shanley, P. (Editors), 2011, Non-timber forest products in the global context

43. SUNDERLIN, WILLIAM D. 2005. Livelihoods, Forests, and Conservation in Developing Countries: An Overview. World Development Vol. 33, No. 9, pp. 1383-1402, 2005, doi:10.1016/j.worlddev.2004.10.004

44. TARIGAN, J., ROSHETKO, J.M., MARTINI, E, EKADINATA, A. 2010. Non-timber forest products as a source of livelihood diversification for local communities in the Batang Toru Orangutan Conservation Program.Working paper 118. Bogor, Indonesia: World Agroforestry Centre (ICRAF) Southeast Asia Program.

45. THARAWADY DISTRICT FOREST DEPARTMENT. 2010. District Forest Management Plan (2005-2015).

46. TIN MOE. 2005. Study of NTFP-resources and their local use in two distinct forest formations of Myanmar, M. Sc. Thesis, Tharandt, Germany

47. TUN, K. 2009. Myanmar forestry outlook study. FAO Regional Office for Asia and the Pacific. Bangkok, Thailand

48. UNDP. 2011. Integrated household living conditions survey in Myanmar (2009-2010): poverty profile. Jointly conducted by Ministry of National Planning and Economic Development and United Nations Development ProgrammeMyanmar, UNDP; Yangon, Myanmar

49. UBERhUAGA P., SMiTh-HALl, C., Helles F. 2011. Forest income and dependency in lowland Bolivia. Environ Dev Sustain (2012) 14:3-23, DOI 10.1007/s10668-011-93068

50. VASUNDHARA. 1998. Non-timber forest products and rural livelihoods, A study in Bolangir and Nuapada districts with special focus on Existing Policy and Market Constraints

51. VEDELD, P., ANGELSEN, A., SJAASTAD, E., BERG, G. 2004. Counting on the environment: forest environmental incomes and the rural poor. World Bank, Environmental Economics Series. No.98

52. VEDELD. P. ET AL. 2007. Forest environmental incomes and the rural poor. Forest Policy and Economics 9 (2007) 869-879

53. WUNDER, S. ET AL. 2014. Forests, Livelihoods, and Conservation: Broadening the Empirical Base, World Development http://dx.doi.org/10.1016/j.worlddev.2014.03.007 